\title{
The Training Needs of the Mathematics Teachers in the Light of Integrating Technology in Teaching at Jordan Country from Their Perspectives
}

\author{
Fadi Bani Ahmad ${ }^{1}$, Haitham Qawaqneh",, Salam Abu Qwider ${ }^{1}$ \\ ${ }^{1}$ Faculty of Educational Sciences, Middle East University, Jordan \\ ${ }^{2}$ Department of Mathematical Sciences, Faculty of Science and Technology, Al-Zay toonah University, Jordan
}

Received January 9, 2020; Revised March 2, 2020; Accepted March 12, 2020

Copyright $\odot 2020$ by authors, all rights reserved. Authors agree that this article remains permanently open access under the terms of the Creative Commons Attribution License 4.0 International License

\begin{abstract}
The process of identifying training needs is an important factor for training teachers in general and mathe matics teachers in particular, which helps to achieve the desired goals of the educational process. This study pointed to distinguish the training needs of the Mathematics teachers in the light of integrating technology in teaching from their points of view. The descriptive approach, which branches into the methodology of studies of mutual relations, was used as a research methodology and a questionnaire was developed for the training needs of mathematics teachers as a study tool. The study population consisted of all teachers in private schools at Qwaisma district in Jordan country which is (80). The stratified random example of the study was (70) members with (40) females and (30) males. The study conclusion explains that the needs were mediu memphasized on (35) training needs. The result also indicates that there was no statistically significant difference in assessing the training needs of Mathematics teachers belonging to the gender and experience since both of them need training and qualification to integrate technology in education. This study may contribute to enhancing learning among learners, developing their learning outcomes and encouraging teachers to use technology with education in mathematics in particular as a result of the rapid changes and developments that occur in the curricula.
\end{abstract}

Keywords Training Needs, Mathematics Teachers, Integrating Technology in Teaching

\section{Introduction}

What has been imposed on the inputs and outputs of the entire educational system, includes teacher, curriculum, learner, teaching strategies and evaluation methods, which have made educational institutions strive to absorb these changes and work to improve the teaching skills of teachers to deal with it and be able to produce and use knowledge, which helps the development of the educational society rather than information consumer knowledge.

The process of identifying training needs is an important factor for training teachers, which helps to achieve the objectives of the training through the existence of a planned activity based on scientific and practical study to identify the training needs, which are classified into two categories: individual aim to achieve the need of individual or group of individuals who lack the Work knowledge and skills, and collective which involves a wide range of individuals who need knowledge and skills (Laird, 2010).

Recent trends in teacher training emphasize the importance of identify ing the needs of the target group of trained teachers. The success of training is measured by the extent to which the training needs are identified, summarized and compiled. Yuns (2012) claims that any training program that is not based on scientific principles will be of no value and will not work. The training needs of teachers, namely: the entrance to the organization analysis, focuses on the future training events, the introduction of analysis of processes and focuses on identifying the most important knowledge, skills, competencies, abilities and qualities, and the entrance of individual identification, which focuses on measuring the performance of the individual in his skill, and trends needed to develop them (Yuns, 2012).

The process of training and vocational training of teachers on issues that represent the interest of educators in diffe rent countries of the world because of their active role in improving the performance of the teacher and student, and the development of the educational process, the preparation of books, curricula and educational programs 
of importance, may not achieve their objectives unless the teacher has prepared for appropriate practice in the educational situation. Therefore, the process of training teachers should be based on actual training needs, with the aim of making continuous positive changes in their performance, experience and attitudes towards the teaching profession (Taani, 2009).

Svatopluk(2010) noted that training is a vital component of lifelong learning. Therefore, new responsibilities have been placed on the teacher, not only in his field of specialization, but in his understanding, awareness and understanding of the requirements of employing this technology, and in the basic integration of learning.

Also, Hoskins (2010) emphasized the integration of technology into education, noting that it is a great challenge. Teachers face a new generation of learners who know the millennium generation or the digital generation. These learners are fundamentally dependent on the development of their knowledge on the Internet and mobile phones, and Electronic communications.

\subsection{The Study Problem}

As our teaching experience, we think that the identification of the training needs of Mathe matics teachers is the indicator that directs the training towards the right direction. The effectiveness and great execution of Mathematics teachers can be achieved in the light of the integration of technology into education, and many previous studies and educational research have recommended that the most important and necessary needs of teachers are being able to integrate technology into education because it is not only that the teacher undergoes training courses that enable them to use modern technology in education, but that the content of the courses and programs is formulated in the context of their need to integrate technology into education which recommended the development of training programs based on the training needs according to the variables that occur around the principals. As the study of (Odah, 2014) which recommended the need to integrate technology in education, and training teachers to use according to the abundance of their train ing needs, and emphasized several educational conferences on the subject of technology integration in education in light of the training needs of teachers, Education in Jordan (2018), entitled "Future Vision for the preparation of students of faculties of education in the light of global variables." And the Conference on Education: Challenges and Future Prospects (2017) entitled "International Conference on Education Challenges and Prospects" on the latest developments in the field of integrating modern technologies in education in Jordan.

\subsection{Objective and Questions of the Study}

The aim of this study is to identify the training needs of
Mathematics teachers with focus on the integration of technology in teaching in Qwais ma district, and to find out whether the views of the Mathematics teachers of the training needs vary according to gender variables and experience. Specifically, the current study sought to answer the following questions:

What are the training needs of Mathematics teachers with focus on the integration of technology in teaching from their point of view in Qwais ma?

Are there significant statistical differences at the level of $(\alpha \leq 0.05)$ in the training needs of Mathematics teachers in the light of integration of technology in teaching due to the variables (gender, experience)?

\subsection{The Importance of the Study}

Theoretical Importance: The study may be useful in enriching theoretical literature in the area of training needs with focus on of the integration of technology in teaching.

Practical importance: A study of the most important training needs of Mathematics teachers may be useful in light of the integration of technology in teaching. It may also benefit Jordanian private school teachers and decision makers at the Ministry of Education in Jordan to identify training needs in the light of integrating technology into education.

\subsection{Study Terms and Definitions}

Training Needs: (Khalifeat, 59: 2010) defines it as "a set of variables and developments that must be made in the information, skills and attitudes of teachers, to enable them to perform their educational work and improve their performance."

We define it as a set of changes that must be made in the educational performance of mathematics teachers in the light of the integration of technology in education, which leads to the achievement of effective education and measures the degree that the teacher sets himself or herslf for the performance prepared for that purpose.

Education Technology: (Mansoor, 61: 2015) defines it as "a set of standards, methods and tools that act as an integrated system to facilitate and develop the educational process and to increase its effectiveness through the use of the latest scientific research aimed at achieving the objectives of education properly, and a friendly network for both learners and teachers, through the use of human and non-human resources to make education more effective.

We define it as a set of means used for the basic stage of Mathematics teachers, which is concerned with the integration of educational materials and resources with the various electronic devices in order to provide them to contribute to the educational learning process, improve them and work to improve them and make them the best way to receive knowledge. 
Mathematics teacher: We define it as the person who holds a scientific qualification specialized in the Mathematics, teaches students the Mathematics in the private schools of Jordan and has to keep abreast of technological and social development to keep informed of everything that is new in the field of specialization.

\subsection{The Limits of the Study}

Objective limitations: Training needs with focus on the integration of technology in the teaching.

Human Limitations: This study was limited to Mathematics teachers of the lower elementary stage.

Spatial boundaries: This study was limited to private schools in the Qwaisma district.

Time Limits: This study was conducted in the second semester of the academic year 2017- 2018.

The descriptive approach deals with the research problem realistically and limits the researcher's interference of responses of the selected sample. These responses do not accept different interpretations, so the results appear objectively and accurately describing the needs of the teachers that they have.

\subsection{Study Determinants}

The results of this study are determined by the indications of the validity of their tools and their consistency with the Jordanian environment, and the generalization of the results of the study is done only in the society from which the study sample or similar communities were withdrawn.

\section{Theoretical Literature and Literature Review}

\subsection{Training Needs and Importance}

The definitions of training needs varied with a variety of viewpoints. Both Khashab and Saeed (2009) identified training needs as the set of changes and developments required to be made by the teacher in terms of his / her knowledge, teaching skills, and attitudes towards them, so that he / she would be able to carry out the teaching profession in planning, implementation, (Tarawneh, 2011: 7) that the concept of training needs is based on the gap between the level of current performance and the level of performance per capita.

The identification of train ing needs is an important step prior to the design of any training program and is essential to any training and support process. The training needs have been accurately identified, measured and scientifically measured, as they are the best way to determine the amount to be provided for new teachers. Information, skills, trends and experiences are gained in order to increase productivity and improve performance. It is also necessary to plan these training programs from the perspective of the current and future training needs in order to increase the effectiveness of teacher performance and raise the quality of education, and the use of effective teaching strategies at all level of education (Kalahati, 2010). Therefore, the process of identifying needs is an important and critical process for the effectiveness of educational programs (Barakat, 2010). The identification of training needs is the basis for all elements of the training process and is an indicator that guides training. The definition of training needs also helps to focus on good performance and access to the primary objective of training, and the identification of train ing needs indicates the individuals to be trained, the type of training required and the expected results.

The process of determining the training needs of teachers in general and teachers of Mathematics in particular is necessary, as one of the most important elements in the educational process, as improving and developing their competencies to do their work best contributes directly to the achievement of the objectives of the educational process.

\subsection{The Importance of Educational Technology in the Educational Process}

As we know, the educational institutions try to educate as many students as possible with the most reduced costs, the slightest time and the least the exertion, and resort to the utilize of innovation to illuminate the issues that will happen, so that the technology of education has contributed to the education of large numbers of learners in crowded classrooms, as well as the enormous increasing of the human knowledge, the struggle against illiteracy of all kinds, and the help of the learner in the face of modern education. Abu Al Saud (2009) emphasized that the technology of education by entering the educational process developed different teaching methods and methods, solved many educational problems and provided the students with a great deal of knowledge and skills. The importance of educational technology in the educational process is identified by Harbi (2010) stimulating the learner's interest and satisfaction of his needs for learning and the formation of new directions. Gaining experience and increasing the active participation of the learner, making him more willing to learn help to cope with individual differences among learners and lead to the modification of their behavior.

\subsection{Integration of Technology in Education}

The field of education is one of the most important areas that should be concerned with the integration of technology in education, as it is the basis for other fields, as it has become easy for everyone to acquire technology from teachers, students, parents, etc. The integration of 
technology into education is at the heart of the technology-based educational reform that aims at educating the learner and imparting many skills in different ways that mimic all his senses, making it easy to sustain the impact of learning to the students. The importance of integrating technology into education is to improve the quality and effectiveness of education and to solve the problems of overcrowding in classrooms and lecture halls. It is noticeable from the review of statistical textbooks on education that the demand for education in developing countries, especially in Arab countries, is increasing steadily, increasing the pressure on education. In oder to provide an opportunity for sensory experiences as close as possible to real experiences, educational means and educational technology provide real or alternative experiences and bring reality closer to the students' minds to improve the level of education (Stetah and Sarhan, 2007).

Ashwa and Alian (2010) emphasized the role of the teacher in the digital age that he provides the areas of expertise for the learner and follow him and guide him to be able to meet the challenges and continuous changes in life, to achieve such a change that he must be the role of teacher and learner.Teacher is directed to the educational process and learner researcher and explorer. Where the teacher plays an important role in the preparation of the special software used in the clas sroom, he should formu late the educational objectives in an appropriate manner and analyze the content of the study and identify the concepts and facts, ensure the knowledge of the characteris tics of the student development and scientific level and skill to be able to determine the appropriate technological means and presentation of the position of class proficiency.

\subsection{Literature Review}

Abu Laila (2015) conducted a study aimed at identify ing the reality of the performance of Mathematics teachers in the light of contemporary trends. The researcher used the analytical descriptive method and the questionnaire as a study tool. The study sample consisted of all secondary school principals in the Gaza governorates. That the performance of teachers of Mathematics in the light of contemporary trends reached a high degree of appreciation according to the level of evaluation adopted in the study.

Lida, Paola, and Veronica (2017) conducted a study on the integration of teaching technology into ESL in 10 public schools in southern Ecuador, aimed at understanding the current state of technology used in the classroom. (150) students and (15) teachers, and used the questionnaire and observation card as study tools, and the results confirm the lack of use of technology in schools in the state of Ecuador and it is necessary to integrate technology tools in the class room.

Shara study (2018) aimed to identify the training needs of new teachers fro $m$ the point of $v$ iew of the principals of the basic schools in the Directorate of Education in Irbid. The study used the descriptive analytical method. The tool of his study is a survey with (44) questions that distributed to (80) school managers. The results of the study showed that the degree of training needs of the new teachers was medium to all areas of training needs. The results of the study also showed that there were no significant differences due to gender variables, qualifications and years of experience.

The subject of this study dealt with the training needs of mathematics teachers with focus on the integrating technology in education from their point of view in Jordan, and this represents one of the most important points of difference in literature review, where most of the studies in literature review did not include the topic of integrating technology and almost of these studies were interested in the using of technology, as the current study highlighted the level of need for skills Integration of technology with the educational process, as most studies dealt with research in specific parts of technological skills, such as developing programming skills, engineering drawing skills, or specific electronic and electrical skills, and other studies dealt with some of the teaching skills such as pre-teaching skills, or skills of practical presentations, and none of the studies in literature review dealt with technological skills that must be available to the mathematics teacher, and in the expanded form, the current study dealt with designing electronic educational units and the use of social media and multimedia, which indicates the originality and modernity of the subject.

\section{Methodology of the Study}

The researchers used the descriptive approach, which is one of the most important curricula used according to the variables of the current study, to build a list of the training needs needed for mathematics teachers to integrate technology in his or her teaching.

The researchers developed the study tool which is a survey by referring to previous studies in order to collect data, classify, organize and analyse it statistically using the (SPSS) statistical program.

\subsection{Study Society}

The study population is one of the teachers of the Mathematics for the basic stage in private schools in the capital Amman for the academic year 2018-2019. The number of Mathematics teachers reached 80.

\subsection{The Study Sample}

The size of the sample was determined based on the size of the community and selected by the random stratified method.

The sample of the study consisted of (70) teachers, 30 of them males and 40 females representing $87.5 \%$ of the original population of the study. (80) Question naires were distributed and (70) of the mare retrieved. Table (1) shows 
the distribution of the study sample according to the study variables.

Table 1. Distribution of the Sample of the study according to Variables

\begin{tabular}{|c|c|c|c|c|}
\hline \multicolumn{2}{|c|}{ Variable } & number & Percent & Total \\
\hline \multirow{2}{*}{ Sex } & Male & 30 & .942 & \multirow{2}{*}{70} \\
\cline { 2 - 4 } & Female & 40 & 57.1 & \\
\hline \multirow{3}{*}{$\begin{array}{c}\text { Years of } \\
\text { Experience }\end{array}$} & Less than 5 years & 36 & 51.4 & \multirow{2}{*}{70} \\
\cline { 2 - 4 } & 5 years-10 years & 18 & 25.7 & \\
\cline { 2 - 4 } & 10 years and over & 16 & 22.9 & \\
\hline
\end{tabular}

\section{Study Tool}

The study tool is a survey that was developed by reviewing theoretical literature and previous studies related to the training needs of mathematics teachers with focus on the integration of technology in teaching. The study tool was used in its final form, consisting of (35) paragraph on training needs. The five-level Likert ladder was adopted. Five levels were defined: Very high, high, medium, low, very low.

Table 2. Total performance correlation coefficients

\begin{tabular}{|c|c|c|c|}
\hline $\begin{array}{l}\text { Paragraph } \\
\text { number }\end{array}$ & Paragraph & \begin{tabular}{|l|l|}
$\begin{array}{l}\text { Coefficient } \\
\text { correlation }\end{array}$ \\
\end{tabular} & $\begin{array}{ll}\begin{array}{l}\text { Le vel } \\
\text { significance }\end{array} & \text { of } \\
\end{array}$ \\
\hline 1 & Defining the concept of linguistic communication and its components & 0.797 & 0.00 \\
\hline 2 & Learning about teaching and learning resources that help teach Mathematics & 0.878 & 0.00 \\
\hline 3 & $\begin{array}{l}\text { Determining the selection criteria for different Mathematics learning and } \\
\text { learning resources }\end{array}$ & 0.679 & 0.01 \\
\hline 4 & $\begin{array}{l}\text { Preparing teaching and learning resources that enable the design of } \\
\text { non-traditional positions }\end{array}$ & 0.797 & 0.00 \\
\hline 5 & $\begin{array}{l}\text { Producing different types of educational boards according to specific criteria } \\
\text { to achieve the objectives of the lesson }\end{array}$ & 0.790 & 0.00 \\
\hline 6 & Employment of educational models in different educational situations & 0.848 & 0.00 \\
\hline 7 & $\begin{array}{l}\text { Producing educational transparency of all types and employing it in } \\
\text { educational situations in a suitable manner }\end{array}$ & 0.785 & 0.00 \\
\hline 8 & Employment of optical displays & 0.867 & 0.00 \\
\hline 9 & Employment of audio devices in teaching Mathematics & 0.928 & 0.00 \\
\hline 10 & The use of blackboard in the teaching of Mathematics & 0.868 & 0.00 \\
\hline 11 & Video tut orial for teaching & 0.797 & 0.00 \\
\hline 12 & $\begin{array}{l}\text { Employment of cult ural T V programs from terrest rial and satellite channels } \\
\text { in learning positions }\end{array}$ & 0.878 & 0.00 \\
\hline 13 & $\begin{array}{l}\text { Employment of appropriate technological innovations to teach and learn } \\
\text { Mathematics }\end{array}$ & 0.679 & 0.01 \\
\hline 14 & $\begin{array}{l}\text { Selection of available educational programs according to educational, } \\
\text { technical and scientific standards }\end{array}$ & 0.797 & 0.00 \\
\hline 15 & Dealing with your computer's Windows operating system & 0.790 & 0.00 \\
\hline 16 & $\begin{array}{l}\text { Connecting devices attached to the computer such as printer, scanner, } \\
\text { camera and microphone }\end{array}$ & 0.848 & 0.00 \\
\hline 17 & $\begin{array}{l}\text { Learning the components and elements of the Mathematics multimedia } \\
\text { program }\end{array}$ & 0.785 & 0.00 \\
\hline 18 & $\begin{array}{l}\text { Dealing with a program of editing graphics and digital images such as } \\
\text { Photoshopand Painter }\end{array}$ & 0.867 & 0.00 \\
\hline 19 & Employment of the Mathematics presentation program "PowerPoint" & 0.928 & 0.00 \\
\hline 20 & Using Word edit ing program to design Mathematics lessons & 0.793 & 0.00 \\
\hline 21 & Using a multimedia presentation setup program & 0.797 & 0.00 \\
\hline 22 & Employment of multimedia presentations in a learning position & 0.878 & 0.00 \\
\hline 23 & $\begin{array}{l}\text { Employment of the program "Excel" mathematical tables in the analysis of } \\
\text { results }\end{array}$ & 0.679 & 0.01 \\
\hline 24 & Achieving the tasks and roles of the teacher in e-learning & 0.797 & 0.00 \\
\hline 25 & Use the Internet quickly and easily & 0.790 & 0.00 \\
\hline 26 & $\begin{array}{l}\text { Employment of some educational websites on the Internet in a learning } \\
\text { position }\end{array}$ & 0.848 & 0.00 \\
\hline 27 & $\begin{array}{l}\text { Downloading files for teaching various Mathematics skills through the } \\
\text { Internet }\end{array}$ & 0.785 & 0.00 \\
\hline 28 & $\begin{array}{l}\text { Creat ing a multimedia library from various sources to teach Mathematics } \\
\text { online }\end{array}$ & 0.867 & 0.00 \\
\hline 29 & $\begin{array}{l}\text { Employing the study of information through the Internet in a suitable } \\
\text { educational position }\end{array}$ & 0.928 & 0.00 \\
\hline 30 & Preparing and using e-mail in written communication & 0.868 & 0.00 \\
\hline
\end{tabular}




\subsection{Authenticity of the Study Tool}

To verify the authenticity of the tool, the honesty was used as it was presented to a group of experienced and competent members of the teaching staff working in 10 Jordanian universities and taking the observations and recommendations proposed by the arbitrators. Table (2) show the total performance correlation coefficients.

The results of the analysis indicate that there are high correlation coefficients and statistical function $(\alpha \leq 0.05)$, which means the internal consistency of the study instrument and its suitability for use.

\subsection{Stability of the Study Instrument}

The researchers verified the stability of the study instrument by using the Cronbach alpha coefficient (0.984) by applying to a sample of 10 teachers and the value of the half-term stability factor (0.950). These values are considered high and suitable for achieving the objectives of the study.

\subsection{Study Variables}

Independent variables: gender, number of years of experience.

Affiliate variables: training needs of Mathematics teachers.

\subsection{Statistical Processing}

Researchers adopted the statistical program (SPSS) for statistical data processing and analysis to reach the results by using the Cronbach Alpha method to calculate the stability of the study tool and the arithmetic averages to calculate the average grade of the individuals in the questionnaire, and the standard deviations to identify the extent to which the grades of the students' estimates were divided on the points and areas of the questionnaire. T-test was to examine differences according to sex variable. And $\mathrm{p}$ - test was to examine differences according to the variable of experience.

\section{The Results}

Answer the first question: What are the training needs of Mathematics teachers in the light of the integration of technology in teaching from their point of view in Qwaisma?

The researchers calculated the arithmetical averages, standard deviations, grade, and degree of appreciation for the questionnaires based on the training needs of Mathematics teachers in the Jordanian private schools in the Qwais ma district in the field of technology integration in education, as shown in the table 3.

It is clear from Table (3) that the values of the arithmetic mean ranged between (2.78-3.71). The standard deviations ranged between $(0.93-0.76)$. The total arithmetic mean (3.35) was a standard deviation of 0.74 and a medium degree of estimation, which means that the training needs were moderately estimated. It was found that 16 of the questionnaire items as shown in Table (1) obtained the highest mathematical averages as the needs of the Mathematics teachers. This is due to the fact that the teachers who responded were in high need due to the lack of training and good preparation in light of the integration of technology in education. In addition, a moderate degree of appreciation is due to the lack of training courses, or the incompatibility of courses with the times of the teacher within the school, which leads to the absence of training courses, hence the need to limit the training needs of Mathematics teachers and diagnosis in the light of the results related to the Mathematics teacher will contribute to the development of the educational system and train teachers to integrate technology into education.

Answer the second question:

Are there significant statistical differences at the level of $(\alpha \leq 0.05)$ in the training needs of Mathematics teachers in the light of the integration of technology in teaching due to the variables (gender, experience)?

First: Gender

To determine whether there were statistically significant differences in the level of significance $(\alpha \leq 0.05)$ in the training needs of Mathematics teachers in the light of the integration of technology in teaching due to the sex variable, the researchers used the $\mathrm{T}$ test for two independent samples and the table 4 is the results of the analysis. 
Table 3. The arithmetical averages, standard deviations, grade and degree of appreciation for the questionnaires based on the training needs of Mathematics teachers in Jordanian private schools in the Qwaisma district in the light of the integration of technology in education. (H: High, M: Medium, L: Low)

\begin{tabular}{|c|c|c|c|c|c|}
\hline Number & Paragraphs & SMA & Standard deviation & The level & Rank \\
\hline 6 & $\begin{array}{l}\text { Employment of educational models in different } \\
\text { educational situations }\end{array}$ & 3.71 & 0.76 & $\mathrm{H}$ & 1 \\
\hline 16 & $\begin{array}{l}\text { Attaching the net work of devices to the computer such as } \\
\text { the printerand scanner }\end{array}$ & 3.71 & 0.76 & $\mathrm{H}$ & 1 \\
\hline 26 & $\begin{array}{l}\text { Employment of some educational websites online in } \\
\text { educational position }\end{array}$ & 3.71 & 0.76 & $\mathrm{H}$ & 1 \\
\hline 3 & $\begin{array}{l}\text { Determining the selection criteria for different } \\
\text { Mathematics learning and learning resources }\end{array}$ & 3.54 & 0.81 & $\mathrm{H}$ & 1 \\
\hline 5 & $\begin{array}{l}\text { Producing different types of educational boards and using } \\
\text { them to achieve lesson objectives }\end{array}$ & 3.54 & 0.98 & $\mathrm{H}$ & 1 \\
\hline 6 & $\begin{array}{l}\text { Employment of educational models in different } \\
\text { educational situations }\end{array}$ & 3.54 & 0.91 & $\mathrm{H}$ & 1 \\
\hline 7 & $\begin{array}{l}\text { Producing educational transparency of all kinds and } \\
\text { employing it in educational and linguistic situations }\end{array}$ & 3.54 & 0.81 & $\mathrm{H}$ & 1 \\
\hline 13 & $\begin{array}{l}\text { Employment of appropriate technological innovations to } \\
\text { teach and learn Mathematics }\end{array}$ & 3.54 & 0.98 & $\mathrm{H}$ & 1 \\
\hline 15 & Handling your computer's Windows operating system & 3.54 & 0.91 & $\mathrm{H}$ & 1 \\
\hline 17 & $\begin{array}{l}\text { Learning the components and elements of the Mathematics } \\
\text { multimedia program }\end{array}$ & 3.54 & 0.89 & $\mathrm{H}$ & 1 \\
\hline 23 & $\begin{array}{l}\text { Employment of the program "Excel" mathematical tables } \\
\text { in the analysis of results }\end{array}$ & 3.54 & 0.81 & $\mathrm{H}$ & 1 \\
\hline 25 & Using the Internet quickly and easily & 3.54 & 0.91 & $\mathrm{H}$ & 1 \\
\hline 27 & Download various Mathematics files via the Internet. & 3.54 & 0.86 & $\mathrm{H}$ & 1 \\
\hline 8 & Employment of optical displays & 3.52 & 0.86 & $\mathrm{H}$ & 2 \\
\hline 18 & Deal with your computer's Windows operating system & 3.52 & 0.86 & $\mathrm{H}$ & 2 \\
\hline 28 & $\begin{array}{l}\text { Creating a multimedia library from various sources to } \\
\text { teach Mathematics online }\end{array}$ & 3.52 & 0.86 & $\mathrm{H}$ & 2 \\
\hline 4 & $\begin{array}{l}\text { Preparing teaching and learning resources that enable the } \\
\text { design of non-traditional positions }\end{array}$ & 3.37 & 1.05 & M & 3 \\
\hline 14 & $\begin{array}{l}\text { Selection of educational programs ready according to } \\
\text { educational standards }\end{array}$ & 3.37 & 1.05 & M & 3 \\
\hline 24 & Achieving the tasks and roles of the teacher in e-learning & 3.37 & 1.05 & M & 3 \\
\hline 32 & $\begin{array}{l}\text { Using some social networking programs through the } \\
\text { Internet to communicate in Mathematics and exchanging } \\
\text { experiences }\end{array}$ & 3.37 & 1.05 & M & 3 \\
\hline 33 & Creating a website to teach Mathematics & 3.30 & 0.99 & $\mathrm{M}$ & 4 \\
\hline 9 & Employment of audio devices in teaching Mathematics & 3.27 & 1.05 & $\mathrm{M}$ & 5 \\
\hline 10 & $\begin{array}{l}\text { Employment of cult ural TV programs from terrestrial and } \\
\text { satellite channels. }\end{array}$ & 3.27 & 1.00 & M & 5 \\
\hline 19 & $\begin{array}{l}\text { Employment of the Mathematics presentation program } \\
\text { "PowerPoint" }\end{array}$ & 3.27 & 1.04 & M & 5 \\
\hline 29 & $\begin{array}{l}\text { Employment of the online learning service in an } \\
\text { appropriate manner }\end{array}$ & 3.27 & 1.04 & M & 5 \\
\hline 30 & Preparing and using e-mail in written communication & 3.27 & 1.00 & $\mathrm{M}$ & 5 \\
\hline 2 & $\begin{array}{l}\text { Learning about teaching and learning resources that help } \\
\text { teach Mathematics }\end{array}$ & 3.20 & 0.79 & M & 6 \\
\hline 12 & $\begin{array}{l}\text { Employing cultural television programs in teaching } \\
\text { positions in a manner }\end{array}$ & 3.20 & 0.79 & M & 6 \\
\hline 22 & $\begin{array}{l}\text { Employment of multimedia presentations in the } \\
\text { educational situation }\end{array}$ & 3.20 & 0.79 & M & 6 \\
\hline 20 & $\begin{array}{l}\text { Utilizing a Word editing program in the design of learning } \\
\text { resources }\end{array}$ & 3.15 & 0.91 & M & 7 \\
\hline 1 & $\begin{array}{l}\text { Defining the concept of linguistic communication and its } \\
\text { components }\end{array}$ & 3.09 & 1.24 & M & 8 \\
\hline 21 & Using a multimedia presentation set up program & 3.08 & 1.24 & $\mathrm{M}$ & 8 \\
\hline 34 & $\begin{array}{l}\text { Design of electronic learning modules for Mathematics } \\
\text { skills }\end{array}$ & 2.98 & 0.80 & M & 9 \\
\hline 31 & Setting up and using a Chat program for communication & 2.87 & 0.77 & $M$ & 10 \\
\hline \multirow[t]{2}{*}{35} & $\begin{array}{l}\text { Having a knowledge repository about integrating } \\
\text { technology into education }\end{array}$ & 2.78 & 0.93 & M & 11 \\
\hline & & 3.35 & & & \\
\hline
\end{tabular}


Table 4. T-Test for two independent samples

\begin{tabular}{|c|c|c|c|c|c|c|}
\hline Performance & Sex & SMA & Standard de viation & T & F & Level of significance \\
\hline \multirow{2}{*}{ Training Needs } & Male & 3.29 & 0.88 & .5830 & 69 & \multirow{2}{*}{.5620} \\
\cline { 2 - 6 } & Female & 3.40 & 0.63 & & & \\
\hline
\end{tabular}

Table 5. Results of the One Way Analysis ANOVA

\begin{tabular}{|c|c|c|c|c|c|c|}
\hline Performance & Sex & SMA & S.D & T & F & Le vel of significance \\
\hline \multirow{2}{*}{ Training Needs } & Male & 3.29 & 0.88 & .5830 & 69 & \multirow{2}{*}{.5620} \\
\cline { 2 - 6 } & Female & 3.40 & 0.63 & & & \\
\hline
\end{tabular}

It is noted from the previous table that there are no gender differences. The value of $(5,830)$ is at the level of significance (.620). This value is not significant at $(\alpha \leq 0.05)$. This is evident from the convergence of the values of the arithmetic averages according to the sex variable.

Second: Experience

To find out if there are statistically significant differences in the level of significance $(0.05 \alpha \alpha)$ in the training needs of Mathematics teachers in the light of the integration of technology in education due to the variable of experience, the researchers used the analysis of the single variance ONE WA Y ANOVA and the table 5 was the results of the analysis.

There are no differences due to experience with a value of (.3090) at the level of significance (.7350). This value is not statistically significant at $(\alpha \leq 0.05)$ and this is evident from the convergence of values of arithmetic averages according to the difference of experience.

The results showed that there were no statistically significant differences $(\alpha \leq 0.05)$ in the training needs of Mathematics teachers in the light of the integration of technology in education due to the variables of gender and experience. From the convergence of the values of the arith metic averages according to the gender variable, all of them are similar, whether male or female, and educational developments are the same for everyone. Everyone understands the need for training and development to adapt to these developments. This is also due to the fact that males and females in private schools in Qwaisma have undergone the same conditions of training and guidance. As for the variable of experience, the results showed that there were no statistically significant differences $(\alpha \leq 0.05)$ in the training needs of Mathematics teachers in the light of the integration of technology in education. The researchers believe that this result is logical since the experience is not different from teacher to teacher. And their gender may need training. This may be due to the weakness of the potential for integrating technology into education in private schools in the Qwaisma district, which affects teachers' experience in terms of integrating modern technology into the education process.

The training and planning of integrating the technology in education is one of the most important skills that mathematics teachers should master.
Planning in education represents an organized method, method and method for work, and it is a purposefully organized mental process that leads to achieving the goals set effectively. The planning helps the teacher to confront educational situations with high confidence and morale as indicated by a study mechanism (Prodromou, Lavicza; 2017).

In order for the teacher to integrate technology tools in education, he must master the use of modern teaching strategies and change his role from a source of information to new roles to become an active student. Since all you need to plan is practical, it must be the teacher to be able to plan profes sionally.

\section{Recommendations}

Through the results of the current study, the researchers recommend the followings:

- Working to increase the awareness of Mathematics teachers of the importance of integrating technology into education.

- Encouraging Mathematics teachers to enroll in technology integration programs in education.

- Holding courses and workshops for teachers related to the integration of technology in education.

\section{Author Contributions}

All authors contributed equally in writing this article and approving the manuscript.

\section{Funding}

This research received external funding from MEE University in Jordan.

\section{Acknowledgements}

The author is grateful to the Middle East University, Amman, Jordan for the financial support granted to cover the publication fee of this research article. 


\section{REFERENCES}

[1] Abu Al Saud, Hani Ismail (2009). A technical program based on the simulation method for the development of some of the knowledge skills in the science curriculum of the ninth grade students in Gaza (unpublished master thesis), Islamic University, Palestine, Gaza.Abu Laila.

[2] Hussein (2015). The reality of the performance of Mathematics teachers in the light of contemporary trends (unpublished master thesis), Al-Azhar University, Gaza.

[3] Ashwa, Fawzi Fayez and Alian, Rabhi Mustafa (2010). Technology of Education (Theory and Practice), I 1, Amman: Dar Al Masirah for Publishing and Distribution.

[4] Barakat, Ziad (2010). The training needs of the teacher in the lower elementary stage from the point of view of the primary school teachers in Tulkarm, Palestine, a scientific paper presented to the third scientific conference of Jerash University entitled "Arab teacher education and rehabilitation: contemporary visions" held on 6-9/4.

[5] Prodromou; T, Lavicza Z. (2017): Integrating technology into mathematics education in an entire educational system - reaching a critical mass of teachers and schools, International Journal for Technology in Mathematics Education, v24.3.04DOI: 10.1564/tme_v24.3.04

[6] Conference of the Faculty of Educational Sciences (2018). "Future Vision for the Preparation of Students of Faculties of Education in Light of Global Variations", Mutah University, 16-18 / 4/2018.

[7] Conference on Education: Challenges and Prospects (2017) "International Conference on Education Challenges and Prospects" Yarmouk University, Irbid College of Education, Jordan, 25-27 April 2017.

[8] Harbi, Obaid bin Mazal Obeid (2010). The Effectiveness of Educational Games on Educational Achievement and Survival of Learning Effect in Mathematics (unpublished Master Thesis), Umm Al Qura University, Makkah Al Mukarramah.

[9] Khalhati, Zahra Hamoud (2010). Training Needs for Basic Education according to their Future Role in Mathematics Education and Learning in the Sultanate of Oman (unpublished Master Thesis), King Qaboos University, Sultanate of Oman.

[10] Khalifeat, Essam Attallah Hussein (2010). Determination of training needs to ensure the effectiveness of training programs, 1, Jordan: Dar Safa for publication and distribution.

[11] Khashab, Adeeb and Said, Hisham (2009). "Towards Building a Tool for Assessing Training Needs of Faculty Members of Technical Education in the Republic of Iraq", Journal of the Union of Arab Universities, 26 (3), 213-234.

[12] Mansoor, Ahmed (2015), Education Technology (First Edition), page 61, Jordan: Janadriyah Publishing and Distribution.

[13] Shara, Asaad Mohammed Mustafa (2018). "The Training
Needs of New Teachers from the Point of View of Principals of the Basic Schools in the Directorate of Education of Bani Obaid / Irbid in Jordan", Journal of Educational and Psychological Sciences, Issue No. 18. Volume II.

[14] Stetah, Dalal and Sarhan, Omar (2007). E-Learning Technology, Amman: Wael Publishing House.

[15] Taani, Hassan (2009). Amman: Dar Al Shorouk for Publishing and Distribution.

[16] Tarawneh, Tahseen (2011). Identifying Training Needs as a Basis for Training Planning in the Security Services (Unpublished Master Thesis), Naif University for Security Sciences, Riyadh, Saudi Arabia.

[17] Yuns, Abdel Fattah (2012). Administrative training between theory and practice, Riy adh: King Saud University Press.

[18] Bates, C. \& Eatson, M. (2008). Re-Leaching techniques to be effective in hybrid and online courses. Journal of American Academy of Business.

[19] Hoskins, J. (2010). "The Art of e-teaching", Journal of Continuing Higher Education.

[20] Laird, D. (2010). "Approaches to Training and Development", Wesleypub1 Company, Massachusetts, pp. 220- 240.

[21] Svatopluk, P. (2010). In- service training of teacher- Issues and Trends. University of Central Florida, Dissertation Abstract International. Supplementary Materials: The following are available online at www.mdpi.com/xxx/s1, Figure S1: title, Table S1: title, Video S1: title. 